\title{
Evaluation of Fruit Quality, Chromatic Parameters and Anthocyanin's Content Under Foliar Application of Magnesium and Potassium on Sweet Cherry (Prunus avium L.) cv. Burlat ${ }^{\dagger}$
}

\author{
Marlene Santos 1,2,3,*(D), Helena Ferreira ${ }^{2,3} \mathbb{D}$, Marcos Egea-Cortines $4 \mathbb{D}$, João Ricardo Sousa 5 , \\ Fernando Raimundo $2,3,5$ (D), Manuela Matos $1,2,3$ and Berta Gonçalves ${ }^{2,3,5}$ (D)
}

check for updates

Citation: Santos, M.; Ferreira, H.;

Egea-Cortines, M.; Sousa, J.R.;

Raimundo, F.; Matos, M.; Gonçalves, B. Evaluation of Fruit Quality,

Chromatic Parameters and

Anthocyanin's Content Under Foliar Application of Magnesium and

Potassium on Sweet Cherry (Prunus avium L.) cv. Burlat. Biol. Life Sci. Forum 2021, 3, 47. https://doi.org/ 10.3390/IECAG2021-09905

Academic Editor: Youssef Rouphael Published: 6 May 2021

Publisher's Note: MDPI stays neutral with regard to jurisdictional claims in published maps and institutional affiliations.

Copyright: (C) 2021 by the authors. Licensee MDPI, Basel, Switzerland. This article is an open access article distributed under the terms and conditions of the Creative Commons Attribution (CC BY) license (https:// creativecommons.org/licenses/by/ $4.0 /)$.
1 Department of Genetics and Biotechnology (DGB), University of Trás-os-Montes e Alto Douro, 5000-801 Vila Real, Portugal; mmatos@utad.pt

2 Centre for the Research and Technology of Agro-Environmental and Biological Sciences (CITAB), University of Trás-os-Montes e Alto Douro (UTAD), 5000-801 Vila Real, Portugal; helenaf@utad.pt (H.F.); fraimund@utad.pt (F.R.); bertag@utad.pt (B.G.)

3 Inov4Agro-Institute for Innovation, Capacity Building and Sustainability of Agri-Food Production, University of Trás-os-Montes e Alto Douro, 5000-801 Vila Real, Portugal

4 Institute of Plant Biotechnology, Campus Muralla del Mar, Polytechnic University of Cartagena, 30202 Cartagena, Spain; marcos.egea@upct.es

5 Department of Biology and Environment (DeBA), University of Trás-os-Montes e Alto Douro, 5000-801 Vila Real, Portugal; jricardo@utad.pt

* Correspondence: mpsantos@utad.pt

† Presented at the 1st International Electronic Conference on Agronomy, 3-17 May 2021; Available online: https://iecag2021.sciforum.net/.

Keywords: anthocyanins; chromatic parameters; fruit quality; magnesium; potassium; sweet cherry

Sweet cherries are seasonal fruits, considered one of the most popular spring and summer fruits in temperate regions of Europe due to their attractive appearance, taste, colour and sweetness, having a high economic importance.

In the North of Portugal, the Resende region is the main area responsible for the total cherry production due to their excellent edaphoclimatic conditions. Thus, potassium (K) and magnesium $(\mathrm{Mg})$ nutrients were applied at the foliar level in sweet cherry trees (cv. Burlat) in an orchard located in the Resende region, at low and high doses $\left(50 \mathrm{~g} / \mathrm{hL}^{-1}\right.$ and $100 \mathrm{~g} / \mathrm{hL}^{-1}$ of K (Enermax - potassium oxide, $\mathrm{K}_{2} \mathrm{O}$ ), $125 \mathrm{~g} / \mathrm{hL}^{-1}$ and $250 \mathrm{~g} / \mathrm{hL}^{-1} \mathrm{of} \mathrm{Mg}$ ) and control treatment $\left(100 \mathrm{~g} / \mathrm{hL}^{-1}\right.$ of $\mathrm{K}$ and $\left.250 \mathrm{~g} / \mathrm{hL}^{-1} \mathrm{of} \mathrm{Mg}\right)$, with the aim to increase cherry quality by crop nutrition. Using fruits harvested in May 2020, at their commercial ripening stage, this study intended to analyse the parameters related to fruit quality as biometric parameters, total soluble solids (TSS), $\mathrm{pH}$, titratable acidity (TA) and maturity index (TSS/TA), as well as chromatic parameters. The anthocyanin's content was also determined by a $\mathrm{pH}$ differential method.

In general, the control treatment presented fruits with a higher weight and size, while fruits treated with potassium at a high dose had lower values. Regarding TSS, pH, TA and TSS/TA, the values were similar among all treatments. However, TSS was lower and TA was higher in cherries treated with a high dose of potassium, which means that this treatment provoked a delay in fruit maturation (the maturity index was lower). The opposite occurred in cherries treated with a lower dose of potassium (higher TSS and lower TA means higher TSS/TA; therefore, anticipating fruit harvest). Concerning chromatic parameters, higher values were obtained in cherries treated with a high dose of potassium, which means lighter cherries, while lower values were found in the treatment with a low dose of magnesium and, consequently, indicate darker and redder cherries. These results can also be correlated with anthocyanin's content, as cherries treated with a high dose of 
potassium presented the lowest anthocyanin content and cherries treated with a low dose of magnesium had the highest anthocyanin content.

Supplementary Materials: The following are available online at https:/ /www.mdpi.com/article/10 .3390/IECAG2021-09905/s1.

Author Contributions: Conceptualization, M.S., H.F., M.E.-C., J.R.S., F.R., M.M. and B.G.; methodology (lab work), M.S. and H.F.; methodology (field work), M.S., J.R.S. and F.R.; writing-original draft preparation, M.S.; writing-review and editing, M.E.-C., M.M. and B.G.; supervision, M.E.-C., M.M. and B.G. All authors have read and agreed to the published version of the manuscript.

Funding: This research was funded by "Fundo Europeu Agrícola de Desenvolvimento Rural (FEADER)" and by "Estado Português" in the context of "Ação 1.1 «Grupos Operacionais»", integrated in "Medida 1. «Inovação» do PDR 2020_Programa de Desenvolvimento Rural do Continente" Grupo Operacional para a valorização da produção da Cereja de Resende e posicionamento da subfileira nos mercados (iniciativa n. ${ }^{\circ} 362$ ).

Institutional Review Board Statement: Not applicable.

Informed Consent Statement: Not applicable.

Data Availability Statement: Not applicable.

Acknowledgments: Marlene Santos acknowledge the financial support provided by the FCT-Portuguese Foundation for Science and Technology (PD/BD/150257/2019), under the Doctoral Programme "Agricultural Production Chains-from fork to farm" (PD Conceptualization, M.S., H.F., M.E.-C., J.R.S., F.R., M.M. and B.G.; methodology (lab work), M.S. and H.F.; methodology (field work), M.S., J.R.S. and F.R.; writing - original draft preparation, M.S.; writing-review and editing, M.E.-C., M.M. and B.G.; supervision, M.E.-C., M.M. and B.G. All authors have read and agreed to the published version of the manuscript." /00122/2012). The authors also acknowledge the support of National Funds by FCT-Portuguese Foundation for Science and Technology, under the project UIDB/04033/2020.

Conflicts of Interest: The authors declare no conflict of interest. 